\title{
Pengelolaan dan Pengembangan Usaha BUMDes Desa Kawiley Kecamatan Kauditan Kabupaten Minahasa Utara
}

\author{
Herman Karamoy $^{*}$, Victorina Tirayoh ${ }^{2}$ \\ 1,2Program Studi Akuntansi, Fakultas Ekonomi dan Bisnis \\ Universitas Sam Ratulangi
}

*Penulis Korespondensi. Email: hkaramoy@yahoo.com

\begin{abstract}
ABSTRAK
Sejak tahun 2014, tepatnya setelah undang-undang tentang desa Nomor 6 telah diterbitkan, pemerintah mulai mendorong pemerintahan desa untuk dapat mengelola dana anggaran untuk desa secara mandiri melingkupi beberapa aspek dan program ekonomi unggulan yang ditujukan guna penyerapan dana anggaran untuk desa yang lebih berdaya guna. Salah satu kegiatan yang dilakukan desa yaitu dengan membentuk Badan usaha Milik Desa (BUMDes). Desa Kawiley Kecamatan Kauditan Kabupaten Minahasa Utara merupakan salah satu desa yang memiliki BUMDes dengan nama Kawiley Indah, kegiatan utama yang dijalankan adalah usaha pinjaman modal usaha. Oleh karena itu telah dilaksanakan program kemitraan masyarakat ini dengan tujuan untuk pengenalan mengenai aturan, maksud dan tujuan BUMDes, Pengenalan tentang usaha-usaha kreatif yang pernah ada dan dilakukan oleh pengurus BUMDes di Indonesia, Mengenali dan memanfaatkan potensi desa untuk pengembangan usaha BUMDes, Pengenalan manajemen usaha BUMDes dalam hal produksi, keuangan, pemasaran, dan sumber daya manusia. Target dari kegiatan ini adalah Pemerintah dan pengurus BUMDes Kawiley Indah dapat mengenal dan memahami aturan, maksud dan tujuan BUMDes, Memiliki wawasan usaha-usaha kreatif yang pernah ada dan dilakukan oleh pengurus BUMDes lainnya di Indonesia, Mengenali dan memanfaatkan potensi desa untuk pengembangan usaha BUMDes, Mengetahui dan mempraktekkan manajemen dalam mengelola usaha BUMDes dalam hal produksi, keuangan, pemasaran, dan sumber daya manusia. Selain itu juga dalam suasana pandemi Covid-19 tim telah menyerahkan perlengkapan yang sangat dibutuhkan saat ini yaitu masker.
\end{abstract}

Kata kunci: BUMDes, Kreativitas Usaha, Manajemen Usaha

\section{ABSTRACT}

Since 2014, to be precise after the law on village number 6 was issued, the government has begun to encourage village governments to be able to manage budget funds for villages independently covering several aspects and superior economic programs aimed at absorbing more efficient village budget funds. One of the activities carried out by the village is to form a Village Owned Enterprise (BUMDes). Kawiley Village, Kauditan District, North Minahasa Regency is one of the villages that has a BUMDes with the name Kawiley Indah, the main activity being carried out is a business capital loan business. Therefore this community partnership program has been implemented with the aim of introducing the rules, goals and objectives of BUMDes, Introduction to creative efforts that have existed and carried out by BUMDes administrators in Indonesia, Recognizing and utilizing village potential for BUMDes business development, Introduction to management BUMDes businesses in terms of production, finance, marketing, and human resources. The target of this activity is that the Government and the management 
of the Kawiley Indah BUMDes can recognize and understand the rules, purposes and objectives of BUMDes, have insight into creative businesses that have existed and been carried out by other BUMDes administrators in Indonesia, Recognize and utilize village potential for BUMDes business development, Know and practice management in managing BUMDes businesses in terms of production, finance, marketing, and human resources. In addition, in the atmosphere of the Covid-19 pandemic, the team has handed over the equipment that is very much needed at this time, namely masks.

Keywords: BUMDes, Business Creativity, Business Management

\section{PENDAHULUAN}

\section{Analisis Situasi}

Setiap desa memiliki potensi yang beragam. Mengetahui potensi ekonomi desa menjadi sangat penting saat ini, karena merupakan salah satu langkah awal dalam upaya meningkatkan kualitas ekonomi di seluruh pelosok negeri. Sekitar kurang lebih sepuluh tahun terakhir, pemerintah telah gencar menggenjot ekonomi daerah. Caranya melalui beberapa program yang ditujukan ke desa-desa. Tujuannya adalah untuk pemerataan pembangunan dan ekonomi, sebagai wujud dari nilai yang terkandung dalam Undang-Undang Dasar 1945. Ada banyak sekali potensi daerah yang dapat digali. Salah satunya adalah dengan program BUMDes. Sejak tahun 2014, tepatnya setelah Undang-Undang tentang Desa diterbitkan, pemerintah mulai mendorong pemerintahan desa untuk dapat mengelola dana anggaran untuk desa secara mandiri. Tentu, dengan melingkupi beberapa aspek dan program ekonomi unggulan. Tujuannya adalah untuk penyerapan anggaran desa yang lebih berdaya guna.

BUMDes adalah badan usaha yang seluruh atau sebagian besar modalnya dimiliki desa melalui penyertaan modal langsung yang berasal dari kekayaan desa. Lembaga ini merupakan salah satu cara yang dilakukan sebagai kekuatan yang akan bisa mendorong terciptanya peningkatan kesejahteraan dengan cara menciptakan produktivitas ekonomi bagi desa dengan berdasar pada ragam potensi yang dimiliki desa.
Sejak diterbitkannya Undang-Undang Nomor 6 Tahun 2014 Tentang Desa, pemerintah desa dituntut untuk dapat mengelola dana anggaran desa secara mandiri. Mandiri dalam arti bahwa anggaran dana desa yang dikucurkan pemerintah pusat, dapat merangsang tumbuhnya sumber-sumber ekonomi desa yang dapat merangsang pertumbuhan ekonomi desa menuju kesejahteraan, yang melingkupi beberapa aspek dan program ekonomi unggulan. Tujuannya demi penyerapan dana desa yang lebih berdaya guna.

Desa Kawiley Kecamatan Kauditan Kabupaten Minahasa Utara memiliki jumlah penduduk sebesar 1.775 jiwa yang terdiri dari 923 laki-laki dan 852 perempuan, dengan jumlah KK 555. Profesi penduduk yang terbanyak adalah sebagai PNS dan Buruh Pabrik serta swasta. Berdasarkan observasi awal dan hasil wawancara dengan Pemerintah desa dan masyarakat yang ada di Desa Kawiley ditemukan bahwa Desa Kawiley memiliki banyak potensi sumber daya alam dan sumber daya manusia yang dapat dikelola untuk mendatangkan kesejahteraan masyarakat. Secara geografis, Desa Kawiley berada pada jalur KABIMA (Kawasan Bitung Manado) yang merupakan jalur potensial dalam pengembangan Kawasan Ekonomi Khusus, dan Desa ini memiliki 2 Jalan besar yaitu Worang by pass dan Jalur Minawerot.

Sampai saat ini, potensi besar yang dimiliki oleh Desa Kawiley dari sumber daya alam, lingkungan bahkan sumber daya manusia belum tergarap sepenuhnya oleh usaha yang dikelola oleh BUMDes Kawiley Indah. 
(4) Pengenalan manajemen usaha BUMDes dalam hal produksi, keuangan, pemasaran, dan sumber daya manusia.

desa Kawiley bahwa BUMDes yang dimiliki oleh Desa Kawiley ada satu dengan nama Kawiley Indah, dan hanya mengelola satu usaha saja yaitu Pinjaman Modal usaha. Kenyataan ini menunjukkan bahwa usaha yang masih terbatas, padahal pemerintah desa memberikan keleluasaan bagi pengurus BUMDes untuk mengekplorasi potensi yang dimiliki oleh desa. Mengingat potensi desa Kawiley maka ada peluang besar bagi BUMDes untuk dapat menambah bidang-bidang usaha lainnya sambil mempertahankan dan mengembangkan bidang usaha yang sudah digeluti saat ini. Dari uraian analisis situasi di atas maka dapat dirumuskan permasalahan sebagai berikut:

Bagaimana mengelola dan mengembangkan usaha BUMDes yang ada di Desa Kawiley Kecamatan Kauditan Kabupaten Minahasa Utara

\section{TUJUAN DAN MANFAAT KEGIATAN}

Berangkat dari permasalahan utama yang dihadapi maka diperlukan usaha untuk mengatasi permasalahan yang ada melalui kegiatan yang dapat memberikan wawasan pengetahuan dan keterampilan manajemen bagi pengurus BUMDes Kawiley Indah untuk lebih kreatif dalam mengembangkan usaha yang dikelola oleh BUMDes. Melalui program kemitraan kepada masyarakat ini pengurus BUMDes dibekali dengan pengetahuan mengenai peran BUMDes dalam membangun desa, usaha- usaha kreatif yang dapat dilakukan BUMDes, dan pengetahuan serta praktek manajemen usaha melalui kegiatan-kegiatan:

(1) Pengenalan mengenai aturan, maksud dan tujuan BUMDes,

(2) Pengenalan tentang usaha-usaha kreatif yang pernah ada dan dilakukan oleh pengurus BUMDes di Indonesia

(3) Mengenali dan memanfaatkan potensi desa untuk pengembangan usaha BUMDes,

\section{METODE PELAKSANAAN}

\section{Sasaran kegiatan}

Sasaran pelaksanaan kegiatan ini adalah pemerintah dan pengurus BUMDes Desa Kawiley Kecamatan Kauditan Kabupaten Minahasa Utara.

\section{Lokasi kegiatan}

Kegiatan secara umum dilaksanakan di Desa Kawiley Kecamatan Kauditan Kabupaten Minahasa Utara.

\section{Metode yang digunakan :}

Adapun tahap-tahap pelaksanaan kegiatan dalam program ini adalah sebagai berikut:

1. Ceramah / Penyuluhan

Kegiatan ini dilakukan dalam bentuk ceramah serta dialog interaktif dengan pemerintah dan Pengurus BUMDes yang ada. Tayangan-tayangan materi dilakukan menggunakan multimedia ataupun audiovisual agar lebih menarik dan lebih dipahami oleh peserta. Nara sumber adalah tim pakar Ekonomi dan Akuntansi yang menguasai dan juga sebagai konsultan dibidang ini.

2. Pelatihan / Praktek

Pelatihan pembuatan anggaran dan manajemen usaha BUMDes dalam hal keuangan, pemasaran, dan sumber daya manusia. 


\section{HASIL DAN PEMBAHASAN}

Sebelum melaksanakan kegiatan pengabdian ini, maka tim melakukan persiapan-persiapan sebagai berikut :

1. Melakukan studi pustaka tentang Badan Usaha Milik Desa (BUMDes), beserta contoh-contoh BUMDes yang ada di Indonesia yang telah memiliki prestasi dan kemajuan pesat dalam mengelola dan menjalankan BUMDes.

2. Menentukan waktu pelaksanaan dan jadwal pelaksanaan kegiatan pengabdian.

3. Mempersiapkan materi yang akan disampaikan dalam kegiatan pengabdian ini.

Kegiatan pengabdian kepada masyarakat ini dilaksanakan pada hari Jumat, 23 Oktober 2020 pada Jam 09.00 Wita sampai selesai, yang bertempat di aula kantor Desa, Desa Kawiley Kecamatan Kauditan Kabupaten Minahasa Utara. Kegiatan ini diikuti 32 orang yang merupakan Hukum Tua Desa, Perangkat Desa, Pengurus BUMDes Kawiley Indah dan Babinsa serta 3 orang tenaga pengajar (dosen) dan 2 orang mahasiswa dari Fakultas Ekonomi dan Bisnis Unsrat .

Kegiatan diawali dengan doa bersama yang di pimpin oleh Ibu Veronica Rotty yang adalah Kasie Kesra, dilanjutkan dengan sambutan dari Ibu Hukum Tua Desa Kawiley dan kemudian acaranya di serahkan kepada kami tim yang ada. Pelaksanaan kegiatan berupa ceramah dan praktek manajemen sederhana dalam pengelolaan usaha BUMDesa.

1. Ceramah / Penyuluhan

Ceramah diberikan langsung oleh ketua tim Dr. Herman karamoy,SE.MSi.,Ak yang adalah tenaga pengajar (dosen) jurusan akuntansi, Dekan Fakultas Ekonomi dan Bisnis Unsrat periode 2016-2020 yang sekarang menjadi CEO Rumah Sakit Siloam Manado dan yang memiliki banyak pengalaman dalam mengelola suatu bisnis karena beliau pernah menjadi Manajer utama Coco Supermarket Manado.

1. Penyuluhan/Ceramah

Melalui ceramah, peserta diberikan materi mengenai:

(1) Aturan, maksud dan tujuan pembentukan BUMDes,

(2) Contoh Usaha-usaha kreatif BUMDes yang pernah ada dan dilakukan oleh pengurus BUMDes lainnya di Indonesia

(3) Identifikasi potensi desa Kawiley dan peluang pengembangan usaha BUMDes Kawiley Indah

(4) Manajemen usaha BUMDes dalam hal produksi, keuangan, pemasaran, dan sumber daya manusia.

2. Pelatihan manajemen usaha BUMDes Selain ceramah, pengurus BUMDes mempraktekkan manajemen usaha BUMDes meliputi:
a. Membuat perencanaan, pengorganisasian, pengarahan dan pengawasan usaha BUMDes
b. Melakukan pencatatan dan pengelolaan keuangan usaha BUMDes
c. Mengelola tenaga kerja yang dimiliki oleh BUMDes, dan
d. Strategi pemasaran produk/jasa yang dihasilkan BUMDes.




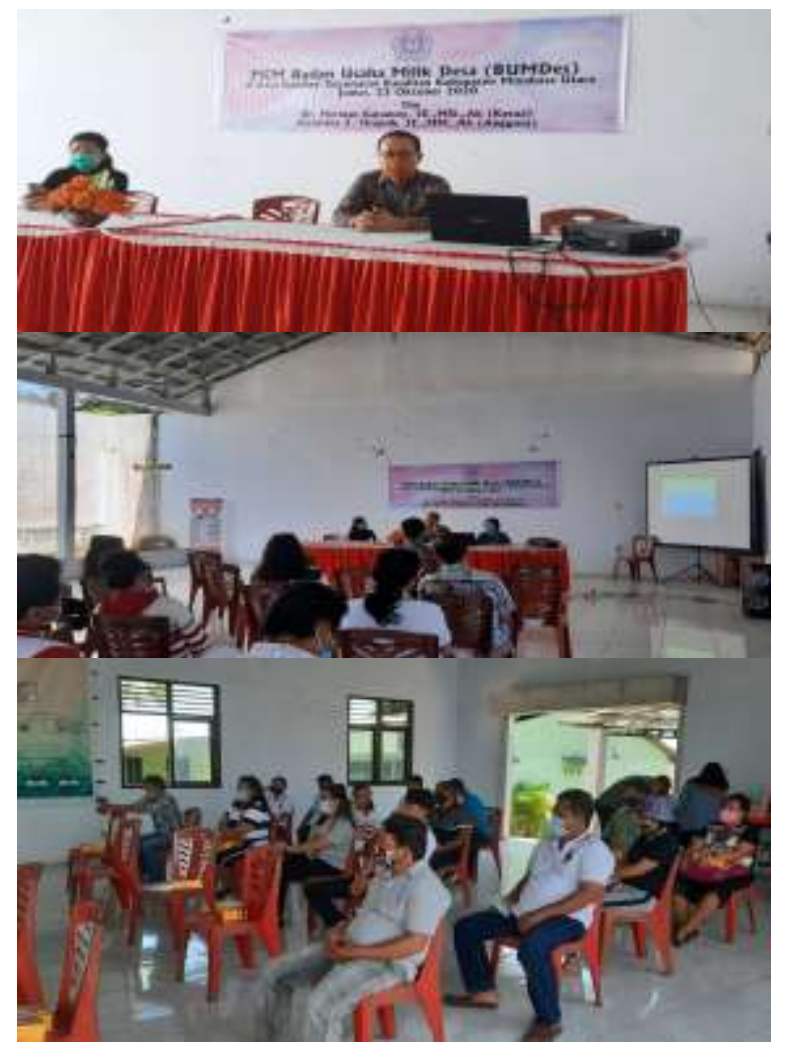

Gambar 1. Foto pada saat kegiatan berlangsung

Diskusi dan tanya jawab mengalir dengan baik dan lancar pada saat kegiatan ceramah maupun praktek. Terlihat para peserta begitu bersemangat menceritakan potensipotensi yang ada di Desa Kawiley. Berbagai motivasi juga diberikan oleh pemateri sehingga boleh tercetus satu ide dari peserta untuk mengembangkan usaha BUMDes Kawiley Indah dari hanya satu usaha yaitu simpan pinjam, dengan jenis usaha lainnya yaitu bisnis kuliner dengan produk unggulan kacang gula merah dan halua kenari.

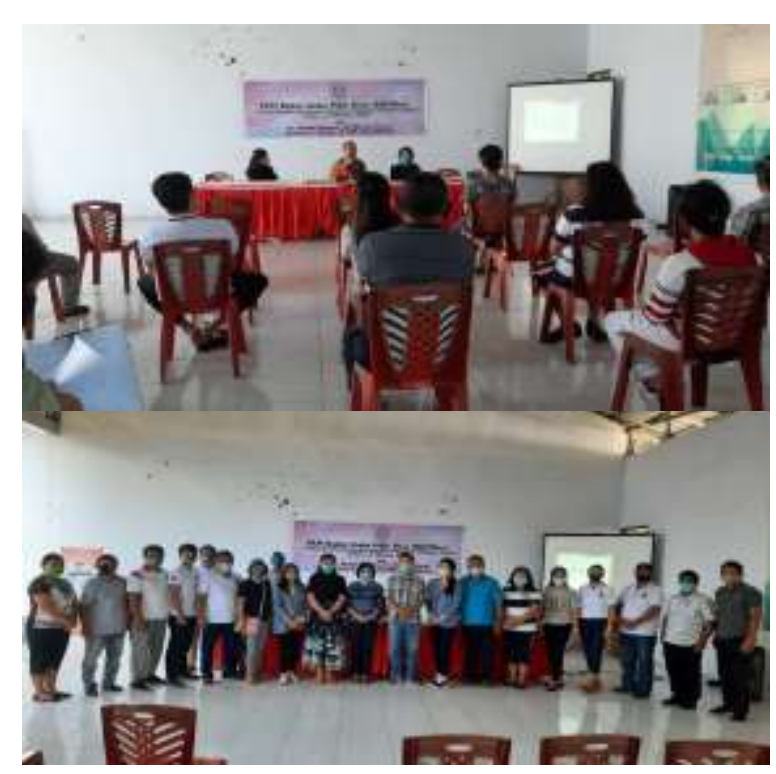

Gambar 2. Foto pada saat kegaitan berlangsung

Antusiasme para peserta merupakan faktor pendukung terlaksananya kegiatan pengabdian ini, meskipun dibatasi oleh waktu karena dalam situasi pandemi Covid-19 namun kegiatan ini dapat dikatakan berjalan dengan baik dan lancar. Dalam kesempatan ini, di akhir kegiatan tim pengabdian melakukan pembagian masker KN95 sebagai bentuk pengabdian turut berjuang bersama dalam menghadapi wabah pandemi Covid-19.

\section{KESIMPULAN DAN SARAN}

Program Kemitraan Masyarakat (PKM) untuk memotivasi dan memberikan pemahaman pengelolaan dan pengembangan Usaha BUMDes Desa Kawiley Kecamatan Kauditan Kabupaten Minahasa Utara telah dilakukan dalam bentuk sosialisasi/penyuluhan serta pelatihan atau praktek. Kegiatan berlangsung secara baik dan lancar berkat dukungan pemerintah yang ada dalam hal ini Ibu Hukum Tua Desa Kawiley Kecamatan Kauditan Kabupaten Minahasa Utara.

\section{UCAPAN TERIMA KASIH}

Terima kasih diucapkan kepada Hukum Tua dan Perangkat Desa, serta pengurus BUMDes 
http://www.keuangandesa.com/2015/ 09/prinsip-tata-kelola-badan-usahamilik-desa/. Accessed July 20, 2016

Suyono, H. 2006. Pemberdayaan Masyarakat: Mengantar Manusia Mandiri, Demokratis dan Berbudaya. Jakarta: Khanata.

Undang-Undang Nomor 6 Tahun 2014 tentang Desa

Undang-Undang Nomor 32 Tahun 2004 tentang Pemerintahan Desa

Abdul, Rosia. 2007. Manajemen Usaha Kecil, Menengah dan Koperasi. Pusat Pengembangan Bahan Ajar. UMB.

Kamanto, S. 2004. Pengantar Sosiologi Perubahan Sosial. . Fakultas Ekonomi UI: Jakarta.

Keputusan Menteri Dalam Negeri Republik Indonesia Nomor: 53 Tahun 2000 tentang Gerakan Pemberdayaan dan Kesejahteraan Keluarga

Kurana. 2008. Sukses Mengembangkan Wirausaha. Jakarta: Grsindo.

Laksana, Nur Chandra, 2018. Jumlah Total Pengguna Media Sosial di Indonesia. Okezone.com

Peraturan Menteri Dalam Negeri Nomor 19 Tahun 2007 tentang Pelatihan Pemberdayaan Masyarakat dan Desa/Kelurahan

Peraturan Menteri Dalam Negeri Nomor 5 Tahun 2007 tentang Pedoman Penataan Lembaga Kemasyarakatan

Peraturan Pemerintah Nomor 72 Tahun 2005 tentang Desa (Lembaran Negara Republik Indonesia Tahun 2005 Nomor 158, Tambahan Lembaran Negara Republik Indonesia Nomor 4587)

Presiden RI Nomor 13 Tahun 2009 tentang Koordinasi Penanggulangan Kemiskinan

Soemarwoto, Otto. 2001. Ekologi, Lingkungan Hidup, dan Pembangunan. Jakarta: Penerbit Djambatan.

Sofyan, A. (2015). Prinsip Tata Kelola Badan Usaha Milik Desa. Keuangan Desa: Media Referensi dan Diskusi Keuangan Desa. 